U.S. DEPARTMENT OF HEALTH, EDUCATION, AND WELFARE

CENTER FOR DISEASE CONTROL

NAT IONAL INST ITUTE FOR OCCUPATIONAL SAFETY AND HEALTH

CINC INNAT I, OHIO 45226

HEALTH HAZARD EVALUATION DETERM INAT ION
REPORT NO. $76-2-292$

PAUL W. FLEMING, D.D.S.

CASPER, WYOMING

MAY 1976

I. TOXICITY DETERMINATION

A health hazard evaluation was conducted by the National Institute for Occupational Safety and Health (NIOSH) on February 11, 1976, at the

Paul W. Fleming Dental Clinic in Casper, Wyoming. At the time of this evaluation, general room samples were taken for inorganic mercury. A direct reading instrument al so was used. Concentrations of mercury during this evaluation ranged from 0.015 to 0.03 milligrams per cubic meter. This is below the NIOSH recommended standard of 0.05 milligrams per cubic meter and is judged not to be a health hazard to the employees.

II. DISTRIBUTION AND AVAILABIL ITY

Copies of this hazard evaluation determination report are available upon request from NIOSH, Division of Technical Services, Information Resources and Dissemination Section, 4676 Columbia Parkway, Cincinnati, Ohio 45226. Copies have been sent to:

(a) Paut W. Fleming, D.D.S.

(b) U.S. Department of Labor - Region VIII

(c) NIOSH - Region VIII

For the purpose of informing the two affected employees, copies of the report shal1 be provided to these employees or the report sha 11 be posted in a prominent place accessible to the employees for a period of 30 calendar days.

\title{
III. INTRODUCTION
}

Section 20(a)(6) of the Occupational Safety and Health Act of 1970 , 29 U.S.C. $669(a)(6)$, authorizes the Secretary of Health, Education, and Welfare, following a written request by any employer or author ized representative of employees, to determine whether any substance normally found in the place of employment has potentially toxic effects in such concentrations as used or found.

NIOSH received such a request fram Paul W. Fleming, D.D.S., Casper, Wyoming, to evaluate the potential hazards associated with exposures to mercury in his dental operatories. 
Page 2 - Health Hazard Evaluation Determination Report 76-2

IV. HEALTH HAZARD EVALUATION

A. Process Evaluated

Dr. Fleming has two dental operatories. A patient is prepared for dental work in one operatory while Dr. Fleming is performing a dental procedure in the other operatory. The basic procedure used when preparing a dental filling is dispensing into a capsule a metal powder such as zinc or silver and then adding elemental mercury to this powder. The capsule is then placed in a shaker, where the mercury and metal are agitated for several seconds. Extreme caution should be taken throughout this procedure in order to prevent mercury exposure to the dentist and his employees. If the capsule containing the mercury and metal is not securely closed or has any leaks, mercury contamination and vaporization would be possible.

B. Evaluation Design

Breathing zone samples and direct reading measurements were taken on Dr. Fleming and his dental assistants in both operatories. These samples were taken using AA filters followed by an organic vapor charcoal sampling tube treated with iodine and designed specifically for mercury collection. The direct reading instrument was a Bacharach mercury detector.

C. Evaluation Methods

A11 breathing zone samples taken on AA filters and organic vapor sampling tubes were analyzed by atamic absorption spectroscopy. Results are presented in Table I.

D. Criteria for Assessing Workroam Concentrations of Air Contaminants

The three sources of criteria used to assess workroam concentrations of air contaminants in this evaluation are: (1) NIOSH recommended criteria for occupational exposures; (2) recommended and proposed threshold 7 imit values (TLV's) and their supporting documentation as set forth by the American Conference of Govermental Industrial Hyg ienists (ACGIH) (1975); and (3) Occupational Safety and Health Standards (29 CFR 1910.1000), U.S. Department of Labor, as of January 1, 1976.

In the following tabulation of criteria, the most appropriate value is presented with its reference and other information footnoted.

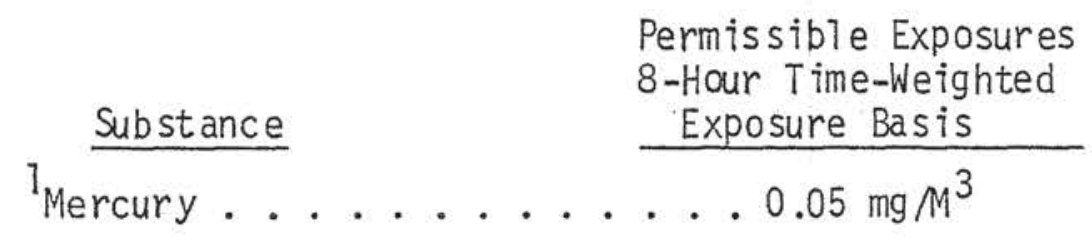

$\mathrm{mg} / \mathrm{M}^{3}=$ approximate milligrams of substance per cubic meter of air 
Page 3 - Health Hazard Evaluation Determination Report 76-2

$T_{\text {Reference: NIOSH recommended criteria for occupational exposures }}$ and recammended and proposed TLV's and the ir supporting documentation as set forth by the ACGIH (1975).

The U.S. Department of Labor legally enforceable standard is $0.1 \mathrm{mg} / \mathrm{M}^{3}$. This is a ceiling concentration and should never be exceeded.

Mercury is a general protoplasmic poison that can be absorbed by inhalation or by ingestion. Mercury and its inorganic compounds may cause dermatitis, visual disturbances, chronic gingivitis, pharyngitis and renal insufficiency. Occupational poisoning due to mercury or its inorganic compounds is usually chronic in nature. Acute mercury poisoning may occur due to massive inhalation of mercury vapor. Acute conditions are 7 imited to the bucco-pharyngeal area. Cases of mercury poisoning with neurologiçal symptoms have also been reported. Compliance with $0.05 \mathrm{mg} / \mathrm{M}^{3}$ of mercury for an 8-hour day, 40-hour work week over a working lifetime should protect workers.

\section{E. Evaluation Results}

A health hazard did not exist, since al1 environmenta 1 measurements were well with in the most recent evaluation criteria. Confidential employee interviews failed to show any health problems. The direct reading mercury vapor detector did not indicate mercury contamination of work clothing or workers' hands throughout the evaluation. All areas of both operatories were monjtored by the direct reading instrument. A11 levels were below $0.02 \mathrm{mg} / \mathrm{M}^{3}$.

F. Recommendations

1. Use tightly closed capsules (screw type capsules other than the push-together type) during amalgamation.

2. Salvage all amalgam scraps and store in a closed conta iner with a layer of water over the amalgam. Store mercury in an unbreakable, tightly sealed container.

3. All mercury spills should be cleaned up immediately, preferably by vacuuming. However, vacuum cleaners should be equipped wi th changeable charcoal filters so that mercury vapor will not escape into the air. Sweeping should be avoided because it creates dust and breaks the mercury into even smaller particles that can vaporize more quickly. 
Page 4 - Health Hazard Evaluation Determination Report 76-2

V. REFERENCES

IInternational Labour Office, Geneva: Occupational Health and Safety, Volume II, 1972, pp 860-863.

VI. AUTHORSHIP

Report Prepared By:

Bobby J. Gunter, Ph.D.

Regional Industrial Hygienist

NIOSH - Region VIII

Denver, Colorado

Originating Office:

Jerame P. Flesch, Acting Chief

Hazard Evaluation and Technical

Assistance Branch

NIOSH - Cincinnati, Ohio 


\section{TABLE I}

AIR CONCENTRATIONS OF MERCURY

Office of Paul W. Fleming, D.D.S.

February 11, 1976

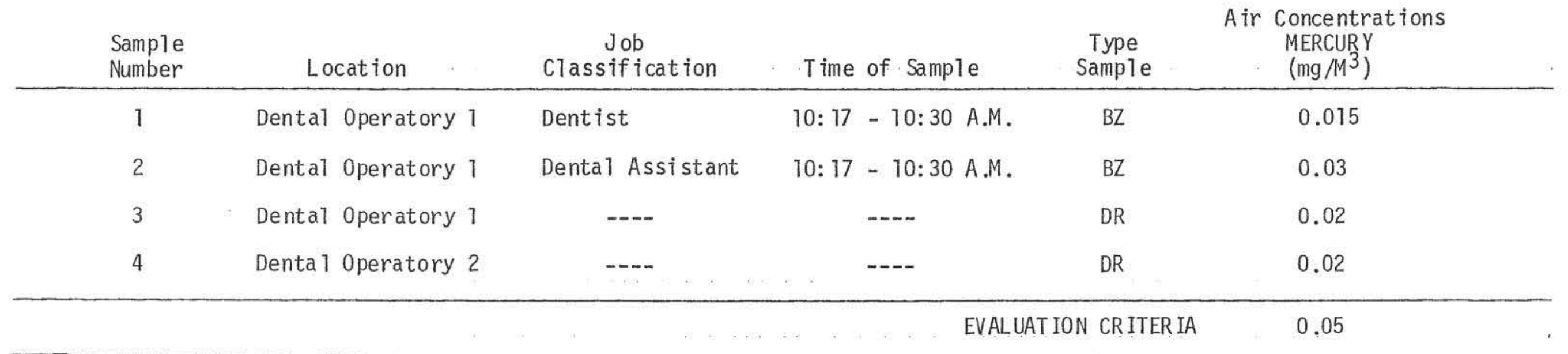

$\mathrm{mg} / \mathrm{M}^{3}=$ approximate mill igrams of substance per cubic meter of a ir

BZ = breathing zone

$\mathrm{DR} \quad=$ direct reading instrument 